\author{
Boris Ljubanović, PhD, Full Professor \\ Josip Juraj Strossmayer University of Osijek, Faculty of Law Osijek \\ Stjepana Radića 13, Osijek, Croatia \\ bljubanovic@pravos.hr
}

\title{
EUROPEAN ADMINISTRATIVE STANDARDS AND PUBLIC ADMINISTRATION IN THE REPUBLIC OF CROATIA
}

\begin{abstract}
After the introductory remarks which, among others, stipulate that the reform and modernization of public administration come from the state autonomy of the Republic of Croatia in the 90s of the previous century and the efforts to go in the path of the western democracies, the author exposes on public administration, local and regional self-government and legal entities with public authorities. Moreover, each of the stipulated segments of public administration is further analysed on the basis of legal structure, current situation and goals and measures for improvement planned by the strategic document of development of Croatian public administration between 2015 and 2020. The author considers new legal regulations on general administrative proceeding and administrative judiciary and subsequently explores the administrative standards of the European Union with key standard being the administrative cooperation among the member states. Croatia has to strengthen the administrative capabilities and develop the standards of European good administrative practice and thus accomplish the necessary Europeanisation of public administration.
\end{abstract}

Keywords: Croatia, public administration, state administration, local self-government units, regional self-government, agency, European Union, European administrative standard

\section{INTRODUCTORY NOTES}

Over the previous years, there have been many scientific - expert conferences in Croatia about the public administration, as well as numerous scientific and expert papers $^{1}$ and important program documentation. There are numerous complex

Public administration was dealt with by the Croatian Academy of Sciences and Arts by holding of round tables with published books Reform of Croatian State Administration, Zagreb, 2006, Croatian State and Administration - Situations and Perspectives, Zagreb, 2008, New Croatian Local and Regional Self-government, Zagreb, 2010 and New Administrative - Territorial Organization of Croatia, Zagreb, 2015. There should also be mentioned the International Conference on Modernization of Croatian Administration that was held in Zagreb with presentations of about twenty foreign and national scientists and experts. Papers from that conference were published in the book Modernization of Croatian Administration, Zagreb, 2003 
issues that need to be resolved, additionally because the public administration comprises the state administration entities (ministries, central government offices, state administrative organizations, state administration departments within the counties), local and regional self-government entities, and all the legal entities with public competencies (agencies, institutes, funds, bureaus, etc....). There was also clearly expressed request for the public administration to be reformed and modernized, as a consequence of state independence of the Republic of Croatia in the 90 s of the previous century ${ }^{2}$ and the obtained possibilities to go in the path of the western civil states. According to the Constitution, Republic of Croatia is a democratic state (Article 2), "the ultimate values of the constitutional order are, amongst others, respecting of human rights, governance of law and democratic multi-party system (Article 3), there has been introduced the principle of the distribution of power (Article 4), principle of constitutionality and legality (Article 5), independent principle of legality in acting of administration and subordinated it to judicial control (Article 19), there has been guaranteed founding of political parties (Article 6), there have been guaranteed personal and political and freedoms and rights, as well as a vast array of economic, social and cultural rights (Part III), among which there is also a right to complaint (Article 18) and the right to entrepreneurial and market freedom (Article 49). ${ }^{3}$ Such social environment requires public service that is up to its social role of executing of legal regulations and exercising of public interests.

However, due to organized armed aggression on Croatia, it could not go in the desired way for a long time after the independence "These are abnormal circumstances of different (external and internal) reasons, where the state authority risks to remain powerless if at supressing them - or removal of their consequences there are forced to act in accordance with the legal norms foreseen for its functioning in regular undisturbed circumstances". Extraordinary situation in the country "had a strong influence on administration, which itself acted in extraordinary

After the referendum of May 22, 1991, Croatian parliament in the session of June 25, 1991 made a Constitutional decision on sovereignty and independence of the Republic of Croatia, Official Gazette, No. 31/91 that stipulates that "by this Act Republic of Croatia initiates the procedure of separating from other Republics and SFRJ. Republic of Croatia initiates the procedure for international recognition". At the aforementioned session, the Parliament also brought the Declaration on sovereign and independent Republic of Croatia (Official Gazette, No. 3/91). After the expiration of a three - month period for the delay of application of the Constitutional decision of June 25, 1991, that was decided by the Brijuni Declaration, at the parliament session of October 8, 1991 the parliament reached a Decision by which "Republic of Croatia, as of October 8, 1991 breaks all state - legal connections on the basis of which it used to form the previous SFRJ together with other Republics and areas and it denies the legitimacy and legality to all the bodies of the former federation - SFRJ (Official Gazette, No. 53/91)

3 Constitution of the Republic of Croatia (Consolidated text), Official Gazette, No. 5/14 
circumstances... it did not start to adjust to the new requirements set before it by the 1990 Constitution but it continued to receive orders from the superiors and to act by them, as it had been done for decades. The only element that changed was the cause of such behaviour: it was now defending of public interests and extraordinary situation that threatened the integrity of the state". ${ }^{4}$

Certain changes of public administration were imposed by the full membership of Croatia in the European Union..$^{5}$ There are, namely, certain standards of public administration and thus the European Union administrative area where those standards are exercised. By inclusion into that area, Croatian public administration has the liability to act according to European administrative standards.

\section{CROATIAN PUBLIC ADMINISTRATION - LEGAL ORGANIZATION AND PRACTICE}

\subsection{State Administration}

\subsubsection{Legal organization}

According to Constitution, Article 117, Paragraph 1, organization and affairs of state administration and the ways they are performed are stipulated by the law. In accordance with that constitutional stipulation, state administration is legally structured by the Legal norms and primarily by the stipulations of the Act on the State Administration System (hereinafter: ASAS). ${ }^{6}$ According to this Act, state administration entities are the ministries, central government offices, state administrative organizations and state administration and state administration offices within the counties. Ministries, central government offices and state administrative organizations are central entities of state administration and state administration offices within the counties are the first instance entities of state administration (Article 3). In order to perform some liabilities of state administration in the competence of central state administration entities, there can be founded regional entities within the county, city and municipality (Article 4).

Ministries are set up to perform the duties of state administration in one or more administrative areas. In the ministries that are set up for more administrative areas, there are usually set up administrative organizations within the ministries such as directorates, institutes and boards (Article 37). The ministry is represented and

\footnotetext{
4 Omejec,J., Legality of Croatian State in Croatian State and Administration, Croatian Academy of Sciencies and Arts, Zagreb, 2008, page 83, 84 and 88

5 Repubic of Croatia became a full member of the European Union on July 1, 2013

6 Act on the State Administration System, Official Gazette, No. 150/11, 12/13, 93/16, 104/16
} 
managed by the minister. They can have one or more state secretaries appointed by the Government after the proposal of the prime minister. Ministry can have one or more assistant ministers. Assistant minister is also appointed by the Government but after the proposal of the minister (Article $39-41){ }^{7}$

Central government offices are set up to perform the liabilities of state administration in one or more administrative areas of special significance for the more effective work of the Government. Central government office is managed by the state secretary (Article 44). ${ }^{8}$ Within the central government office that performs primarily the administrative work, there are founded administrative organizations, as a rule as sectors, with a certain degree of independence (Article 48).

State administrative organizations are set up to perform the liabilities of state administration in one or more administrative areas, as a rule as state directorates, institutes and boards (Article 49). State administrative organizations are managed by the director. They are appointed by the government, after the proposal of the prime minister and with previous opinion of the competent minister (Article 49, 51). ${ }^{\text {? }}$

State administrative offices within the counties are set up to perform the liabilities of public administration in more administrative areas. Their internal structure is determined by the ordinance of the Government. They are managed by the head. They are appointed by the government on the basis of public tender (Article 53, 55 and 56). Office performs administrative and other business within the administrative area for which it is set up, and in particular:

- Directly implements the laws and other regulations and provides their implementation,

- Resolves administrative matters as a first instance, if it is not in competence of central state administrative entities by a separate act or legal entities with public authorities or trusted to local or regional self-government units,

- Implements administrative or inspection monitoring,

- Monitors the situation in its scope (Article 54).

Apart from the state administrative offices within the counties, state administration affairs are also performed within regional units of central state administration entities. It is so called deconcentrated state administration. ${ }^{10}$

Affairs of the Ministries - see Article 38 of ASAS

8 Central State Offices affairs - see Article 44, Paragraph 2 of ASAS

9 State Administration Organization Affairs - see Article 50 of ASAS

10 Compare to Kuhlmann,S., Wollman, H., Introduction to Comparative Public Administration: Administrative Systems and Reforms, Edward Elgar, 2014, p. 132 
In order to perform business of state administration from the competence of state administrative office within the local (regional) self-government, there can be set up branch offices within the cities and municipalities stipulated by the government after proposal of the head of the state administrative office. Branch office is managed by the head of branch office and there are responsible for their work to the head of the state administrative office within the county (Article 59).

Closely describes the responsibilities of the state administration entities. Those entities:

- Directly implement the laws and other regulations (resolve administrative matters, keep inquest registers, issue certificates and other documents) (Article 17),

- Implement administrative monitoring; especially monitor the legality of work and operations, resolving administrative matters, efficiency, cost effectiveness, purposefulness of work, internal structure and ability of officers and employees to perform the duties within the liability of state administration, the relationship of employees and officials with the citizens and clients (Article 20,21),

- Perform inspection monitoring (Article $24-33),{ }^{11}$

- Monitor the situation within their responsibility and on the basis of gathered data, notifications, reports, analyses, etc., implement certain measures and activities (Article 34).

Issuing of implementation regulations and making of draft bills of law and other regulations is within the competence of central state administration entities (Article 18,35$)$.

State administration affairs within the state administration are performed by government officials. They are accepted to government service on the basis of public tender, if the law does not stipulate otherwise. Auxiliary - technical affairs are performed by employees (Article 8).

The work of state administration is public. Public can be excluded only in exceptional cases foreseen by the law (Article 13).

Performing of work of state administration is harmonized and monitored by the government. While that, the government has the authority to:

- Terminate the regulations of state administration entities,

11 Inspection work in the first instance is performed by the state administrative offices within the counties, and in second instance central state administration entities, if the special act does not determine otherwise. Central state administration entities can directly perform inspection within the competence of state administrative offices within the counties (Article 25 of ASAS) 
- Analysed the situation within a certain state administration entity and stipulate the measures that are necessary for that entity to implement,

- Suspend the head of state administration entity,

- Start the procedure to determine the responsibility of officials and employees,

- Implement all other measures in accordance with the law and other regulations (Article 65).

As far as the other stipulations of ASAS are concerned, we herein mention only those that can be complained at the first instance against individual acts, and measures of state administration, and in case where the complaint is not permitted, there can be requested court protection (Article 16); at resolving of administrative affairs ex officio certificates on facts have to be obtained ex officio regarding the matters that are held in official registrars by the state administration entities (Article 82); state administration entities have to enable the citizens and legal entities to complain against their work and the head of the state administration entity has to issue a response to the complaint within 30 days from the day of complaint or objection (Article 84, Paragraph 1 and 4); state administration entities have to inform the public about their work through public media or in any other appropriate way and providing of information shall be withheld when the data is classified or if the information is protected by the act that determines the protection of personal data (Article 77); members of national minorities have the right to be represented in the central entities of state administration and state administrative offices within the counties in proportion to their number in total population of the Republic of Croatia or the county respectively (Article 9).

\subsubsection{State-administration practice}

State administration comprises 20 ministries, 5 state offices, 7 state administrative organizations and 20 state administrative offices within the counties. In order to perform work from the jurisdiction of central entities of state administration within the counties, cities and municipalities, there were set up 1,279 regional central entities of state administration and their branch offices. In order to perform work from jurisdiction of state administrative offices within the counties, there were 91 branch offices and 302 register offices set up in the cities and municipalities. ${ }^{12}$

On January 1, 2015 there was a total of 56,220 government officials and employees in state entities (44,910 government officials and 11,310 employees). Out

12 Croatian Parliament, Strategy of Development of Public Administration from 2015 to 2020, p. 44 
of total number of government officials, 15,981 or $35.58 \%$ had high, 6,484 or $14.44 \%$ higher and 22,445 or $49.98 \%$ high school education.

On January 1, 2015 public services had a total of 151,158 government officials and employees, 129,014 officials and 22,144 employees. 77,876 or $60.36 \%$ of officials had high, 19,958 or $15.47 \%$ had higher and 31,180 or $24.17 \%$ had high school education. ${ }^{13}$

According to the presented structure of state administration, apart from work of state administration from different administrative fields is performed by state administrative offices within the counties, and another part is performed by regional entities of numerous central state administration entities. Such structure of state administration is irrational, both from the aspect of costs and from the aspect of organization of work of state administration. Organization separation of regional entities of central state administration entity in the same area or within the same county disables them from acting harmonically, significantly increases material costs (each ministry performs "their" accounting, computer, additional - technical and other works), which increases the number of government officials and employees. Therefore, it is not surprising to see that almost a half of all government officials is employees in regional entities. It is, therefore, proposed that within the same entity - state administrative office within the county - there is official record and primary resolving of administrative matters that are not very specific (such as, for example, tax and customs administrative matters).

Considering the current issue of relationship between central entities of the state and local self-government and the opinion of administrative - legal science related to it that decentralization of state has no alternative (more on that at 2.2.2), the attention is drawn to the fact that there is a trend of centralization of performing of inspection work in administrative practice, because the inspection work that was primarily at first instance performed at state administrative offices within the counties are taken over by the central state administration entities. This jeopardizes the legal safety because the works from level I and II are performed at the same entity of state administration. ${ }^{14}$

Significant positive results of reform of public administration, which means state administration as well are as follows: strengthened utilization of information and communication technology in public administration (e-administration), especially with the system e-Citizens which has been available since June 2014; there was upgraded openness and transparency of public administration by application of

\footnotetext{
13 Strategy as in footnote 13, p. 30-31

14 Strategy as in footnote 13 , p. 45
} 
Act on the Right of Access to Information from 2003; there was set up a system of internal financial control of public administration by the Act on Internal Financial Control System in Public Sector ${ }^{15}$; there has been improvement of strategic planning in state administration entities; there has been set up a system of evaluation of legal regulations effectiveness; there has been upgraded the system of education and training of government officials; there have been taken measures for strengthening the ethics in state services.

Strategy of public administration development for the period between 2015 2020 that was accepted by the Croatian parliament on June 12, 2015, among other special goals of public administration system reform foresees the "rationalized administration system" and measures to "rationalize internal structure of public administration entities", "adjoining of regional entities of central state administration entity with the state administrative offices within the counties" and "transferring of certain inspection work in the first instance and the works of deciding in administrative affairs in the first instance from the central state administration entities to the state administrative offices within the counties". ${ }^{16}$

\subsection{Local and regional self - government}

\subsubsection{Legal structure}

Local and regional self-government is legally structured by the constitution, Act on Local and Regional Self - Government from 2001, with subsequent alterations and amendments (hereinafter: ALRSG) ${ }^{17}$ as well as by other acts that structure the issues of this self - government. European Charter of Local Self-government was ratified by the decision by Croatian Parliament in $1997^{18}$ and thus, in accordance with Article 141 of the Constitution, it became a part of internal legal order of the Republic of Croatia. By the Constitution, citizens are guaranteed the right to local and regional self-government. This right is exercised through local and regional representative bodies that consist of members elected in free and secret elections on the basis of direct, equal and general elective right. Citizens can also directly participate in local businesses through assemblies, referendums and other forms of direct decision-making in accordance with the law and statute (Article 133). The Capital of Zagreb can, by law, be given a position of the county, and major cities can get the authorities of a county. In the community, or a part of it,

\footnotetext{
15 Act on Internal Financial Control System in Public Sector, Official Gazette, No. 78/15

16 Strategy as in footnote 13 , p. 53-54

17 Act on Local and Regional Self - Government, Official Gazette, No. 33/01, 60/01, 129/05, 109/07, $125 / 08,36 / 09,150 / 11,144 / 12,19 / 13,137 / 15$

18 European Charter of Local Self-government, Official Gazette, International Treaties, No. 14/97
} 
in accordance with the law, there can be founded forms of local self-government (Article 134). Local and regional self-government units have the right, within the law, to structure the internal order by their acts, as well as to structure the scope of their activities and to adjust them to the local needs and possibilities; they have the right to own revenues that they can autonomously distribute to perform the activities from their scope. Revenues must be in accordance with their authorities foreseen by the Constitution and law. Weaker local self-government units have to be supported by the state, in accordance with the law (Article 136, 138). Local and regional self-government units are independent in performing the work within their scope and they can only be monitored on the grounds of constitutionality and legality by the authorized state entities (Article 137).

According to ALRSG, local self-government units are cities and municipalities, and regional self-government units are counties. Municipalities, cities and counties are founded by the law (Article 3). The City of Zagreb, as the capital of the Republic of Croatia, is a separate and unique territorial and administrative unit, the structure of which is determined by the Act on the City of Zagreb (Article 2).

Municipality is founded, as a rule, for the area of more settlements that present a natural, economic and social unit and are related to common interests of the citizens.

City is a local self-government unit that is also the capital of the county, as well as any settlement with over 10,000 citizens, and presents an urban, historical, natural, economic and social unit. The city can comprise suburban settlements that create the economic and social unit with the city and are connected by daily migratory movement and needs of citizens. Exceptionally, the status of a city can be awarded to a settlement that does not meet the aforementioned criteria, if they are special reasons for that (historical, economic, geographical and transportational).

County is a regional self-government unit, the area of which presents a natural, historical, transportational, economic, social and self-government unit and it is set up for the purpose of performing works of regional interest (Article $4-6$ ).

Municipality, city and county are legal entities (Article 9). Municipalities and cities perform the works of local significance that directly meet the requirements of the citizens, and that are not, by the Constitution or law, awarded to state entities and especially works that are related to physical planning and housing, communal economy, child care, social welfare, primary healthcare, upbringing and elementary education, culture, physical education and sport, protection of consumers, protection and promotion of natural environment, fire protection and civilian 
protection, as well as transportation in the area and all other works in accordance with special act (Article 19).

ALRSG also recognizes the category of large cities. Those are the cities with over 35,000 citizens and that are economic, financial, cultural, health, transportational and scientific centre of the extended area. Apart from the works of municipalities and cities, large cities and capitals of counties also have the authority to perform works related to issuing of construction and location permits and other construction related documents and implementation of physical planning documentation, as well as maintenance of public roads. However, large cities and capitals of counties can, in their area, also perform works from the scope of the county (Article 19a, 21).

Counties perform works of regional significance, and especially works related to education, healthcare, physical planning, economic development and transportation infrastructure, public road maintenance, planning and networking of educational, health, social and cultural institutions, issuing of construction and location permits and other construction related acts, implementation of physical planning documentation for the county area outside the large city, as well as other works in accordance with the special act (Article 20).

Previously stipulated works awarded to local and regional self-government units by ALRSG, which can be extended by special acts, present their self-government scope. However, according to ALRSG, Article 23, the act also determines the works of state administration that are performed in the local and regional selfgovernment unit. This is the, so called, transferred scope of self-government units because the works that are transferred to them still remain state administrative works. European Charter of Local Self-Government, which became an integral part of Croatian legal order after ratification, also recognizes the, so called, optional self-government activity of the local self-government units, according to which they can independently determine the works to perform in accomplishing the local interests, if it is not opposing the legal order. ${ }^{19}$

Representative bodies of local and regional self-government are municipal council, city council and county assembly. The number of their members depends on population, and they are elected for the period of four years. A member of the representative body performs the duty honourably and is not paid for it, but has the right to remuneration, in accordance with the decision of the representative body

19 See Koprić, I., Territorial Organization of Croatia: according towards the new structure, in New Administrative - Territorial Organization of Croatia, Croatian Academy of Sciences and Arts, Zagreb, 2015, p. 24 
(Article 27 - 31). Meetings of the representative body are public, except the special situations that are foreseen by the law and general act of the unit (Article 37).

Executive body in the municipality is the municipality mayor, in the city a city mayor and in the county a county prefect. They are elected, just like their deputy, at direct elections, in accordance with the special act (Article 39, 40). They are present at the meetings of the representative body and they submit a report on their work to that body, on a half-yearly basis (Article 35b, 37). They can, together with their deputy who was elected with them, be suspended by the referendum. The decision on their suspension is made if the suspension was chosen by the majority of voters who voted and if that majority presents at least $1 / 3$ of total voters listed in the voters' registrar with the municipality, city or county (Article 40b, 40c). Municipality mayor, city mayor and county prefect represent the municipality, city or the county. They are responsible to the central state administration bodies for performing of works of state administration transferred to the scope of the municipality, city or the county (Article 42).

In order to perform works from the self-government scope of the local and regional self-government, as well as of works of state administration transferred to those units, there are founded administrative departments and services (administrative bodies). A single administrative department is founded in the municipalities and cities with up to 3,000 people, and in the municipalities and cities with population of more than 3000 there can be founded more than one administrative department. Administrative departments are managed by the heads who are, on the basis of public tender, appointed by the municipality mayor, city mayor or the county prefect (Article 53, 53a).

Apart from the stipulations on local and regional self-government, ALRSG also contains the stipulations on settlement self-government. Local community councils are a form of direct participation of citizens in decision making in local affairs of direct and daily influence to life and work of citizens. They are founded by the statute of the local self-government for a settlement or a part of a larger settlement or mutually connected smaller settlements, or the city that in relation to the other parts forms a separate divided unit. Bodies of the local community council are assembly of the local community council, members of which are elected at direct elections, by secret voting, and the president of the assembly of the local community council. Assembly of the local community council is elected by the citizens who have the right to vote, and the member can be a citizen with the right to vote and with residence in the area of the local community for which the members are elected (Article 57, 61). 
Local and regional self-government units have their assets that comprise all movables and immovable and property rights belonging to them (Article 67). They have the revenues within their scope which they autonomously dispose of and that is determined in Article 68 of ALRSG (such as municipality, city or county tax, surtax, fees, contributions and duties, revenues from assets of units and property rights as well as others). They have their budget, which is proposed by the only authorized proposal maker, municipality mayor, city mayor or the county prefect (Article $67-69$ ). Material and financial operation of the municipality, city and the county is monitored by the representative body, and the legality of their operations is controlled by the Ministry of Finance or other institution determined by the law (Article 71, 72).

Against the individual acts of municipal and city administrative bodies that resolve administrative matters, there can be filed a complaint to the administrative body of the county, or there can be started an administrative dispute. Against some individual acts in administrative affairs that are decided in the first instance by the administrative bodies of the council and large cities, there can be filed a complaint to the competent ministry, if the special law does not prescribe otherwise, or there can be started an administrative dispute (Article 76). However, against the individual acts of the representative body or the municipality mayor, city mayor or the county prefect that resolve the administrative matters, there cannot be filed a complaint, but there can only be started an administrative dispute (Article 77a).

Monitoring of legality of operations of the representative body of the local and regional self-government unit is performed by the central state administration entity competent for the local and regional self-government. It has the right to, in case of determined irregularity, by their own decision, declare a session of the representative body or a part of it illegal and to make the acts from such a session void. In the cases determined by the law, the government shall, at proposal of the aforementioned central state administration entity, dissolve the representative entity. If the budget is not brought within the legal time frame, or there is no decision on temporary financing, the government shall, at the same time, dissolve the representative entity and suspend the municipality mayor, city mayor or the county prefect and their deputy who was elected with them and the government shall appoint a commissioner to perform the works of the representative and executive body and call an early election. Against the aforementioned decisions of the central state authority entity, or the government, there can be started an administrative dispute (Article 78a, 85a-85c).

The monitoring of legality of general acts of the representative body of the municipalities, cities and counties is performed by the state administrative offices within 
the counties and competent central state authority bodies, each in their scope, in accordance with the special act (Article 79).

\subsubsection{Local and regional self-government in practice}

From the previous expose, we can see that according to Croatian legislation there is local, regional and local community self-government; self-government units are municipalities and cities (local), counties (regional), and one settlement or more related settlements or a part of a larger settlement or a city that form a separate divided unit (local community); city is every settlement with over 10,000 citizens (including the surrounding and suburban settlements) that presents urban, historical, natural, economic and social unit, and the capital of the county; status of the city can also be awarded to the settlement that does not meet the required criteria if there are special reasons (historical, economic, geographic, transportational); large cities are those with over 35,000 citizens and that are economic, financial, cultural, healthcare, transportational and scientific centres of the broader area; local and regional self-government units have their self-government scope, transferred scope and by the European Charter of Local Self-Government, optional self-government scope.

According to this summarized and closer (previously in 2.1) presented legal structure of local and regional self-government, there are 17 large cities in the Republic of Croatia and 8 cities with the authorities of larger cities (although they are below 35,000 citizens), because they are capitals of counties. ${ }^{20}$ There are founded 576 local and regional self-government units, 555 of which local self-government unit (428 municipalities and 127 cities), 20 regional self-government units i.e. counties, and the City of Zagreb as the capital of the Republic of Croatia with the special status of the city and the county.

On December 31, 2014 there were 13,683 government officials and employees in the local and regional self-government units, 11,920 of which were government officials and 1,763 were employees.

Duties of the municipality mayors, city mayors, county prefects and their deputies are performed by 1,322 people, 428 being municipality mayors and 481 deputy municipality mayors, 127 city mayors and 211 deputy city mayors, 20 county prefects and 52 county prefect deputies, and the mayor of Zagreb and 2 of his deputies. $^{21}$

\footnotetext{
20 In accordance with data of the Citizen Census from 2011

21 Strategy, as in footnote 13 , p. 47
} 
There are great differences among the counties, both in their size and in the population. By area, the largest is Lika - Senj County $\left(5,353 \mathrm{~km}^{2}\right)$, and the smallest is Medimurje County $\left(729 \mathrm{~km}^{2}\right)$, so the ratio between the largest and the smallest county is $7.3: 1$. The largest in population is Split - Dalmatia County $(455,242$ citizens), and the smallest in population is Lika - Senj County (51,022 citizens) with the ratio being $8.9: 1$. According to the undivided opinion of the scientific and expert public, the existing local self-government system is not sustainable. Local units are excessively fragmented; due to poor financial abilities, many are lagging behind. Performing of self-government duties awarded to them often depends on the assistance of the central state. Works on education, healthcare and social welfare that are guaranteed by the Constitution to be self-government affairs are performed in only 33 cities, while the remaining units (94 cities and 428 municipalities) do not perform those duties. But even those are duties from the self-government scope only theoretically, due to practice of "decision-making, orders-giving, regulation and financing by the state bodies that defer from the standard of that scope". ${ }^{22}$

When it comes to regional self-government, scientific public expresses the understanding of the need of setting up new balanced regional structure, instead of the current inconsistently formed counties with five regions as geographic, historical and social - economic units.

The scientific literature indicates to necessity of decentralization where the law awards the local and regional self-government bodies with certain affairs from the state administration that they can independently decide on, with the liability of adhering to regulations and with the right of being monitored by the central state bodies that are, as a rule, limited to monitoring of legality of acting of local bodies, and not the regularity of their decisions. ${ }^{23}$

Many regional units of central state administration bodies and legal entities with public authority, as well as state administration offices and their branch offices disable the local units to perform their local work in an integral way. Integrated local administration is performed by cooperation and joining of organizations and people and as such, it assumes the quality providing of public services and local development. ${ }^{24}$

22 Koprić, op.cit. note 20, p. 28

23 Smerdel, B., Constitutional Structure of European Croatia, Narodne Novine Plc., Zagreb, June 2013, p. 486

24 On model of multi-level governance see Bevir, M., Key Concepts is Governance, Sage Publications, 2009, p. 134-137 
It has to be mentioned that the European Commission in June 2014 expressed their opinion that fragmented responsibility of public administration at regional and local level and complex distribution of competencies among the ministries and agencies at the central level make it difficult to reach operational decisions and extend the administrative procedures. Therefore, it was recommended by them to remove the stipulated issues within a short period of time.

In spite of certain efforts ${ }^{25}$, decentralization and new administrative - territorial organization have not been accomplished until today because the key political figures and their political parties, in spite of the all abovementioned, want to keep the current state.

Nevertheless, there might be some hope because the Strategy of Development of Public Administration for the period from 2015 to 2020, among special goals and measures of the reform of providing of public services sets the target of "Goal 17. Rationalized system of local and regional self-government", and: "Measure 17.1 Define the Model of Functional and Fiscal Decentralization"; "Measure 17.2 Determine the Optimum Territorial Structure of the Republic of Croatia". ${ }^{26}$

\subsection{Legal entities with public authorities}

Legal entities that have public authorities are an important segment of public administration. These are organizations of different names that, due to their significant characteristics, can mostly be referred to as agencies or agency - type organizations, disregarding of their official name. Agencies can, namely, be defined as entities that are structurally separated from the state administration system to perform public works at the national level, that employ government officials and are financed primarily from the state budget, and they are subordinate to procedure of public control of legal nature. ${ }^{27}$ Founding of them is related to liberalization and privatization of public services and with entrepreneurial and market freedom. They are based on the idea of regulatory state which, as such, holds the norms of market behaviour or in certain sectors of public services. They often have the authority to resolve individual cases (so called adjudication), implementation of

25 On February 23, 2012, Government of the Republic of Croatia founded the National Committee for Implementation of Decentralization and Reform of Local and Regional Self-Government. President of the Republic, Ivo Josipović, in cooperation with his expert team, made in 2014 a text of constitutional changes that also include regional restructuring, but those efforts remained ineffective

26 Strategy, as in footnote 13, p. 57-58

27 See Koprić, I., (referring to foreign authors), Development and Problems of Agency Model with Special Reflection to Independent Regulators, within Agencies in Croatia, Institute of Public Administration, Zagreb, 2013, p. 13 
monitoring, implementation of sanctions, etc. Their advantages are lower possibility of political and other influences, protecting of general interest and better legal protection of the beneficiaries (consumers), preventing of forming of monopoly, specialization and expertise.

Founding of agencies in certain sector areas was imposed by the European Acquis Communautaire (e.g. protection of market competition, protection in electronic communication, safety protection in airline and railway transportation). We can, therefore, say that founding of agencies was a consequence of Europeanization of Croatian public administration. In that context, more attention should be paid to independent regulatory agencies and similar types of agencies.

Significant characteristics of Croatian independent regulatory agencies are:

- They are founded by a special act (e.g. Act on Croatian Agency for Financial Services Monitoring) or the act that structures a certain activity (e.g. Agency for Medicinal Products and Medical Devices was founded by the Medicinal Products Act),

- They have legal nature and are founded as legal entities with public authorities,

- They are founded on the national level with the purpose of providing of functioning of the market where certain public services are provided according to stipulated rules, or standards (e.g. financial services, electronic communication services); safety of trading of goods and services in a certain area for the protection of safety of people (e.g. transportation, medicinal products); providing of certain standard of quality of services for the beneficiaries (e.g. high education, healthcare and social welfare),

- They have independence (autonomy) in organization (statute determines their organization and acting), personal (freedom of employment and setting of salaries), financial (ensured source of financing, budget, own funds), political (not allowing political and other influences).

Monitoring of agencies is performed by legal supervision (legality of work and application of relevant legal regulations), financial (utilization of financial resources), monitoring of efficiency (accomplishing results), and political monitoring (submitting of report on operations, public manners of operations). ${ }^{28}$

According to data from 2012 and 2013, there were "about 75" organizations of agency type. Independent regulatory agencies had 749 employees, with most of

28 See more by Musa, A., Good Management in Croatian Regulation Agencies: according to legal framework, within Agencies in Croatia, Institute of Public Administration, Zagreb, 2013, p. 117-131 
them in Croatian Post and Electronic Communication Agency (140), and the least in the Croatian Railway Safety Agency (4). ${ }^{29}$ The deficiencies of Croatian legal entities with public authorities are irrational system, non-existence of unique legal structure that results in non-harmonization of regulations, non-justification of founding and costs, insufficient cooperation with the competent ministries, deficiencies in employment and public procurement systems.

Therefore, it should be supported that the strategy of public administration development for the period from 2015 to 2020 within the rationalization of administrative system (Goal 14), foresees structuring of system by trusting of a part of a state administration affairs to legal entities with public authorities (Measure 14.4), and legal structure and rationalization of system of legal entities with public authorities (Measure 14.5). ${ }^{30}$

\section{CROATIAN GENERAL ADMINISTRATIVE PROCEDURE AND ADMINISTRATIVE JUDICATURE}

\subsection{General administrative procedure}

Regulations on general administrative procedure have very high significance for the entire public administration system. New Croatian General Administrative Procedure Act (hereinafter: GAPA) ${ }^{31}$ was brought in 2009 and has been applied since January 1, 2010. It is the law that follows the constitutional structure of the Republic of Croatia after the independence and tries to accept the requirements of relevant international conventions, European Union Acquis Communautaire and general public administration standards.

In this paper we do not deal with general administrative proceedings into depth, but we point out some of the significant stipulations of the existing GAPA, and they are as follows:

- According to GAPA, "public-legal entities" act and resolve matters in legal affairs. This is a new term that comprises the state authority entities and other state entities, local and regional self-government bodies, legal entities with public authorities (Article 1).

- Administrative matter is defined as "any matter where the public-legal entity in the administrative proceeding decides on rights, liabilities or legal interest of a private or a legal entity or other parties, by direct application of laws, other

\footnotetext{
$29 \quad$ Ibid. p. 115, 125-126

30 Strategy as in footnote 13 , page 53,55

31 Croatian General Administrative Procedure Act, Official Gazette, No.47/09
} 
regulations and general acts that structure a certain administrative area. Administrative affair is also considered to be any affair that is legally stipulated as an administrative affair" (Article 2).

- GAPA is also applied, in an appropriate way, in the proceedings of protection of rights or legal interests of parties in affairs in which the legal entities who perform public services decide on their rights, liabilities or public interests, if there is no court practice or any other legal protection stipulated by the law (Article 3, Paragraph 3).

- Public-legal entity has to enable the parties to, if exercising of some of their rights requires more administrative or other proceedings, submit all requests in a single administrative location in public-legal entity, and they shall, without delay, according to formal duty, be submitted to the competent public-legal entities. In the aforementioned location, all parties and other interested entities can obtain the requested forms, notifications, advice and other assistance from the area of public-legal entity (Article 22). In that way, there was accepted the requirement of the European Parliament Directive from 2006 on services in common market, where all the member states have to provide in public authority locations a single location for contact and coordination where the clients can perform all formalities regarding the proceeding. ${ }^{32}$

- In the public-legal entity, the person who acts is an official whose duty is managing of the proceeding or resolving of administrative matters, in accordance with the regulations on structure of public-legal entities. The head of the public-legal entity issues a decision only if there is no person authorized for resolving of administrative matters within the entity (Article 23, Paragraph 1 and 3).

- An official in a public-legal entity can directly resolve the administrative matter without implementation of the examination procedure, in the cases foreseen by the law, if the proceeding does not comprise parties with opposite interests. GAPA lists the cases when an official can directly resolve an administrative matter in the proceeding that was initiated ex officio, or at request of a client (Article $48-50)$.

- Clients with the opposite interest can reach an agreement in total, or on some disputable issues, and the official has the liability to try and reach the settlement during the entire proceeding. It is not permitted to reach the settlement opposed to regulations, public interest or rights of third persons (Article 57).

32 See Article 6, Paragraph 1, Directive 2006/123/EC of the European Parliament and of the Council of 12 December 2006 on Services in the Internal Market within the Official Journal of the European Union as of December 27, 2006 
- In the stipulation that foresees electronic communication, GAPA determines that public-legal entities and clients and other persons in the proceeding can communicate electronically. Public-legal entity is obliged, without delay, to confirm electronically to the sender their receipt of the writ, or if the writ cannot be read due to technical reasons, the sender has to be notified about that (Article 75). Electronic delivery, which can be performed at any time, is performed at request of a client or with a clear consent of a client when it is prescribed by the law (Article 95).

- GAPA foresees assumption of acceptance of the client's request, or in the case of missing the deadlines it is considered that the request of the client is approved (so called fictional administrative act), when it is prescribed by the law and if the proceeding was initiated after the valid request of the client, and the public-legal body has the authority to directly resolve the administrative matter. In that case, the client has the right to request from the public-legal entity to issue decision of acceptance of the request. Public-legal entity is obliged to issue such a decision within 8 days from the day of request of the client (Article 102). With such positive fiction, GAPA went further with so called complex decisions, i.e. decisions in reaching of which there are more public-legal entities in a way that one entity cannot resolve the matter without the consent, confirmation, approval or opinion of another entity. Article 21, Paragraph 1 and 2 stipulate that publiclegal entity has to issue the act on consent, confirmation, approval or opinion or reject to issue such an act within 30 days from the delivery of a valid request for issuing. When the public-legal entity does not decide on the request for issuing consent, confirmation, approval or opinion, it will be considered that the act was issued in favour of the client, if not prescribed otherwise.

- Second instance body shall resolve the administrative matter on the basis of complaint, by analysing the facts determined in the first instance proceeding. However, when the facts have not be fully determined or have been wrongly determined, second instance entity has the liability to complete the proceeding themselves or through the first instance body (Article 115, Paragraph 3). When the second instance body decides on complaint that the decision was not reached timely, and determines that the reasons for not reaching first instance decision were not justified, they resolve the administrative matter themselves or order the first instance body to issue the requested decision within 15 days (Article 119, Paragraph 3).

- Important news is the stipulation on administrative agreements in Article 150 - 154 of GAPA. They prescribe conditions for entering of and subject of administrative agreements, reasons for voiding them, alteration of administrative 
agreements due to altered circumstances, termination of administrative agreement and the complaint to the administrative agreement.

- Public-legal entity is obliged to notify the interested person at their request on conditions, way and procedure to exercise or protect their right or legal interest in a certain administrative matter (Article 155). Person who considers that their right had been violated by illegal act of an official or any other person in the public-legal entity, has the right to file a complaint (Article 156). Protecting of rights of beneficiaries of public services who believes that their rights or public interests have been violated by an act of public services provider, comes down to the right of filing a complaint to the competent monitoring entity, and if they are not satisfied with the measures taken, they can start an administrative dispute (Article 157, 158).

It should be noted that the respectful ministry, at proposal of an expert taskforce, ${ }^{33}$ proposes certain alterations and amendments of GAPA. Attention is drawn, in particular, by the following newly-proposed solutions:

- The principle of protection of legitimate expectations of clients is added to the principles of general administrative proceeding: "In the proceedings that decide on rights or liabilities of clients, public-legal entities have to provide protection of their legitimate expectations".

- There are determined cases of exemption of the expert witnesses and minutes keepers.

- It is determined that the deadline for reaching of decision starts from the day of starting of proceeding at request of a client or ex officio.

- There is foreseen the maximum deadline for filing a complaint and the documents to the second instance body: "If the first instance body does not reject the complaint or does not replace the disputed decision with a new one, they shall, without delay, and the latest within 8 days, submit the complaint with the documentation to the second instance body".

- There shall be limited returning of the proceeding for the retrial by new stipulations: "If the proceeding before the public administration entities was not completed within the two-year period from the day of starting of proceeding, the client has the right to start the administrative dispute".

33 Members of the expert taskforce are: Professor Dario Đerđa, PhD, Professor Boris Ljubanović, PhD, Associate Professor Marko Šikić, PhD, Associate Professor Frane Staničić, PhD, Assistant Professor Bosiljka Britvić Vetma, PhD, and Assistant Professor Lana Ofak, PhD 
- Stipulate that regular legal remedy (whether the complaint or objection) can be used against the decision that does not accept the proposal of the client to cancel or make the decision void.

\subsection{Administrative judicature}

Reform efforts of the Republic of Croatia within the public administration system also comprised the new stipulations on administrative judicature, contained within the new Administrative Disputes Act from 2010 (hereinafter: ADA), ${ }^{34}$ which is applied from January 1, 2012.

The most significant new stipulations of ADA are:

- The goal of the Act, according to the new stipulation from Article 2 is to "provide judicial protection of rights and legal interests of physical and legal entities and other clients that are violated by individual decisions and acts of publiclegal entities". Public-legal entities are the entities of "state administration and other state entities, local and regional self-government units, legal entities with public authorities and legal entities performing public services..."

- Subject of the administrative dispute has been significantly extended to comprise the assessment of legality: a) individual decisions of public-legal entity, b) proceeding of public-legal entity, c) breaching of determined deadlines for decision issuing and $\mathrm{d}$ ) entering, terminating and exercising of an administrative agreement (Article 3, Paragraph 1).

- The law formulates the principles of an administrative disputes as follows: principle of legality, principle of client's statement, principle of oral discussion, principle of efficiency and principle of assistance to uneducated client (Article 5 9). The court can relinquish these principles only in cases stipulated by the law.

- Administrative disputes are resolved at two instances - administrative courts (in Osijek, Split, Rijeka and Zagreb) and High Administrative Court of the Republic of Croatia.

High Administrative Court decides on: a) complaints against verdicts of administrative courts and decisions of administrative courts that can be complained against, b) legality of general acts and c) conflict of interest between the administrative courts (Article 12).

Administrative Court decides in the council of three judges, and as an individual judge in cases described the law. High Administrative Court decides in the council

34 Administrative Disputes Act, Official Gazette, No. 20/10, 143/12, 152/14, 94/16 
of three judges, and on legality of general acts in the council of five judges (Article 14).

- Parties in a dispute are a claimant, a respondent and an interested party. Claimant is a physical or legal entity and can also be a person with no legal entity or a group of people if their rights or legal interests have been violated, but they can also be state entities authorized by the law and public-legal entity that participated or should have participated in decision-making, proceeding or reaching an administrative agreement. Respondent is a public-legal entity (Article 17 and 18).

- The complaint does not delay effectiveness, except when determined by the law. The court can decide for the complaint to have delay effectiveness if by exercising an individual decision or an administrative agreement there would be incurred damage to the claimant that is hard to be remedied, if the law does not stipulate that the complaint does not have delay effectiveness of an individual decision, and the delay is not against the public interest (Article 26).

- The Court resolves the administrative dispute on the basis of public hearing held, and without the hearing only in the cases determined by the Law (Article 36, e.g. if the respondent admitted to the complaint as a whole).

- The Court recognizes the institute of so called exemplary dispute (Article 48). Namely, if in ten or more first instance administrative disputes the subject of the complaint had the same legal and factual nature, the Court can decide which dispute is going to be resolved as an exemplary dispute, and terminate the dispute in others. After the effectiveness of the verdict in the exemplary dispute, the Court continues the terminated disputes with application of evidence from the exemplary dispute.

- The Court has the authority to draw evidence and determine facts and is not bound with the proposals of the parties or with the facts that were determined in the previous administrative proceeding. The Court draws the evidence on the basis of principles of evidence providing in the law proceeding (Article 33).

- The Court relevantly decides on the subject of dispute. By accepting the claim, the Court reaches the so called reformation decision.

- Parties in the administrative dispute can, due to violation of law, propose to State Attorney of the Republic of Croatia to submit a request for extraordinary questioning of legality of final decision of the administrative court or High Administrative Court and this request shall be decided upon by the Supreme Court of the Republic of Croatia (Article 78). 
- The Act brings new stipulations regarding the settling of costs of the administrative dispute (Article 79), exercising of court decisions (Article $80-83$ ), evaluation of legality of general acts given by the High Administrative Court at a public session (Article $83-88$ ), and resolving of administrative dispute by the settlement of parties (Article 89).

Regarding the fulfilment of decision and verdict, fulfilment of a decision by which the court resolved the matter has to be ensured by the respondent, while the decision is fulfilled by the court that reached the decision. If the respondent does not ensure fulfilment of decision in a certain period, the claimant can require the court to exercise the fulfilment of the decision. Fulfilment is exercised according to rules for fulfilment in the general administrative proceeding.

The proceeding of assessment of legality of a general act is started by the High Administrative Court, at request of a private or a legal entity, or a group of people related with the common interest but the request is submitted within 30 days from the day of decision. However, that proceeding can be started by the High Administrative Court ex officio or at request of the court. High Administrative Court decides at public assembly on legality of a general act, with the possibility to have so called advisory hearing prior to it. If they stipulate that the general act is not in accordance with the law or statute of the public-legal entity, the court shall reach a decision to terminate the general act or some stipulations of it.

\section{CROATIAN PUBLIC ADMINISTRATION AND EUROPEAN ADMINISTRATIVE SPACE}

The idea on creating of European Administrative Space was encouraged by the principle of a single meaning and application of the legislation of European Union (hereinafter: Union). According to that principle, the legislation of the Union has to be equally valid in its entire area or in the area of all the member states has to be applied in the same way, which is the basic precondition for reaching the goals and tasks of the Union. Accomplishing of this requirement, assumes among others, suitable public administration system of the member states. Union, however, has no authority to create the model of structuring of public administration of the member states and to require the member states to apply it. It should also be mentioned that even acquis communautaire of the Union does not contain expressed rules on organization of public administration of the member states. Or, in another words, there is no final European solution on how to reach the modern and successful public administration. The principle of administrative autonomy of the member states was accepted by the stipulation of Article 291, Paragraph 1 of the Treaty on the Functioning of the European Union that says: "Member states 
make all the measures of the national legislation necessary for implementation of the legally binding acts of the Union". This is the case of "implementation deficit" because the Union does not have the authority to organize public administration of the member states, although those public administrations apply the legislature of the Union with the requirement that this application should be harmonized and efficient. The importance of this issue, as pointed out by Maartje Verhoeven, should not be underestimated, since the application of the rights of the Union is primarily happening within the national administrative decisions, very few of which end up with court proceedings. The effectiveness of the legislature of the Union in practice greatly depends on its application by the national administrative bodies. ${ }^{35}$ The aforementioned "implementation deficit" is attempted to be removed or at least mitigated by the European Administrative Space as an assembly of the administrative standards of the Union, with the key standard being the administrative cooperation of the member states. According to stipulation of Article 197 of the Treaty on the Functioning of the European Union that has the name "administrative cooperation", efficient implementation of the law of the Union by the member states, which is important for the right functioning of the Union, is considered the issue of common interest. The Union can support the efforts of the member state vested into improvement of their administrative capability to implement the legislation of the Union. Such activity can include alleviating of exchange of information and government officials as well as supporting the program of their training. No member state is bound to use this support. European Parliament and Council deciding by the ordinances in accordance with the regular legal proceeding, for that purpose determine the necessary measures, while excluding any harmonization of the laws and other regulations of the member states. These stipulations have the possibility of strengthening the administrative capacity of the national public administration, i.e. improvement of their ability to implement the laws of the Union.

According to Article 291, Paragraph 2 and 3 of the Treaty on the Functioning of the European Union, when there are necessary unique conditions for implementation of legally binding acts of the Union, these acts award the implementation authority to the Commission or the Council in special, valid cases and cases from Article 24 and 26 of the Treaty on the European Union. ${ }^{36}$ For those purposes, European Parliament and Council through the Ordinances, in accordance with regular legislation procedure, determine the rules and general principles in advance, in

\footnotetext{
35 Verhoeven, M., The Constanzo Obligation, The Obligation of National Administrative Authorities in the Case of Incompatibility between National Lawand European Law, 2011, p. 47

36 The mentioned articles refer to common foreign safety policy
} 
order for the mechanisms for the member states to function in monitoring of the implementation authorities awarded to the Commission.

The aforementioned administrative cooperation makes public administration of the member states become functionally and not structurally or hierarchically part of the European administration. Regarding public administration, there is accomplished "Europeanization as an effect", and not "Europeanization as homogeneity".

That, certainly, refers to Croatian public administration as well. In spite of generally good results, it has to strengthen its abilities and upgrade the standard of good European administration and in that way, fully, functionally join the European Administrative Space.

Apart from the mentioned administrative cooperation, there are other European administrative standards. An important administrative standard is so called administrative capacity of the Union. ${ }^{37}$ Administrative capacities of the Union comprise the ability of public administration of a certain state to participate in shaping and implementation of the European public policy, to implement the European acquis communautaire and the policy of administrative staff. ${ }^{38}$

There is special importance of administrative standards contained in stipulation of Article 6 of the European Convention for the Protection of Human Rights and Fundamental Freedoms that guarantees the right to a fair trial and stipulation of Article 41 of the Charter of Fundamental Rights of the Union that foresees the right to good administration.

Standards of good administration come down to, primarily, the principles of European public administration. These are the following principles:

a) Rule of Law means proceeding by the law or legislature with understanding certain requirements regarding the contents of the Constitution. It is important for functioning of the administration because it excludes arbitrary decision making and requires thorough functioning of legality, division of power, right and fair administrative proceeding, judicial monitoring of administration, etc.

\footnotetext{
37 They were determined by the Commission in their opinion from 1997

38 For more on administrative capacities of the Union see Koprić, I., European Administrative Space Fulfilment of European Standards in the Member States and Candidates, within European Administrative Space, Institute of Public Administration, Zagreb, 2012, p. 167-171
} 
b) Legality means that the activities of administration have to be on the basis and in accordance with the law, valid regulations; it requires the legality of administrative acting and the administration being comprised by the law.

c) Proportionality means that every limitation of freedom or right has to be proportional to the nature of the need for limitation in any specific case.

d) Legitimate expectations mean that legal consequences should be certain for those to whom the law shall apply. They have to be in accordance with the legitimate expectations of the parties in any specific case when the law is applied directly to them.

e) Reliability and predictability. Reliability means absence of arbitrarity in acting of public administration which is accomplished by obeying of the fundamental principle of the legal state (Rechtsstaat) - acting by the law and in accordance with the law. Predictability means that it can be estimated in advance what the decision of the administrative body is going to be. Predictable, safe and clear administrative environment is especially appreciated by foreign and domestic investors. In order to apply these principles, it is necessary to have a fast administrative procedure and professional functioning of administrative officials, which is accomplished by a suitable system of employment and promotion and specific material rewarding.

f) Openness and transparency. Openness means that there have to be conditions for monitoring of public administration from the outside and transparency means that administration itself has to be "transparent" for possible control. Public interest is thusly protected because there is decreased possibility reaching bad decisions, bribe and corruption and the interest of the citizens is protected because there is an open possibility to deny the administrative decisions.

g) Responsibility. Responsibility means: firstly, that administration must make their decisions responsibly and be able to clarify them, and secondly, that administration must be responsible for their decisions and for the ethical nature of their work. This is the issue of responsibility regarding some specific decisions and acting of administrative officials. The supervision of the work of administration can be internal (so called internal controls) and external (by the prosecution, court, ombudsman and parliament).

h) Efficiency and efficacy. These are not synonyms. Efficiency, namely, means a good ratio between the utilized funds and accomplished results, and efficacy means the ability of public administration to accomplish the goals and find solution for the issues of public interest. Principle of efficiency 
is accomplished by increasingly larger practice of contracted, concession signing and delegating of public services to private companies (roads, ports, telephones, waste, etc.), and by some public services entering the market and thus competing with the private sector.

There are, however, some other principles that are accepted in any democratic public administration, and they refer to the public officials and the quality of regulations and actions.

The principles that refer to public officials especially are the following:

a) Impartiality. This principle has two aspects. The first is that religious and point of view of the holder of the public authority, their social connections, personal and family interests cannot influence the contents of administrative decisions and regulations in a sense to be bias. The other aspect of impartiality is the independence of holder of public authority towards the superiors. They have the right to decline the order of the superior which is clearly illegal or doing it would commit a crime.

b) Loyalty. This principle requires: firstly, that the proposal maker has to offer the superior officials, whenever possible, multiple solutions and secondly, that the orders for the subordinate officials must be clear and unambiguous, with exact clear mandate (authority) and means to be used.

c) Material indifference. This principle is manifested as absence of corruption by the administrative officials and absence of cumulating of public services and private activities that lead to conflict of public and private interests.

d) Discretion and reservedness. This is the principle that requires public administration official to refrain from commenting of their professional work and stating of facts from the private area of the beneficiary of public services.

More intensive inclusion of Croatian public administration into the European Administrative Space is one of the goals (Goal 15) placed by the Strategy of Development of Public Administration from 2015 to 2020. They also state the measures for accomplishing of that goal: improving of capacity of state administration bodies to take part in processes of decision-making and shaping of public policies of the European Union (Measure 15.1); improving of application of European administrative principles and standards in every day's work of government officials (Measure 15.2). ${ }^{39}$

39 Strategy, as in footnote 13, p. 56 


\section{CONCLUSION}

Croatian public administration comprises the state administration bodies, local and regional self-government bodies and legal entities with public authorities. Legal structure of the system of state administration enabled the existing, very broad structure of state administration which, apart from central bodies of state administration (ministries, central state offices and state administrative organizations) also make the state administrative offices within the counties, as well as numerous regional units of central state administration bodies and their branch offices (so called deconcentrated state administration). Such administrative structure is irrational, both in respect of costs and in respect of organization of performing of administrative works. Fragmentedness of local central state administration bodies in the same settlements or in the area of the same counties prevents them for being harmonized, significantly increases material costs and the number of employed government officials and employees. Therefore, the strategic document of development of public administration from 2015 to 2020 foresees the rationalization of administrative system, among other things by joining the regional units of central state administration bodies with the state administrative offices within the counties.

Legal regulations that determine local and regional self-government enable, in practice, even further fragmentation of local self-government units (municipalities and cities). Most of these units do not perform the work that are Constitutionally guaranteed self-government works (so called self-government scope), due to financial difficulties, and moreover there are those that they assess they should do because they are of local interest (so called optional self-government scope). With all that, a large network of local central state administration units and legal entities with public authorities, with state administration offices and their branch offices disable the so called integrated local administration. In spite of requirements of scientific and expert public and certain efforts of political factors, decentralization of state administration affairs and new administrative - territorial organization have not been accomplished yet.

Legal entities with public authorities are organizations of different names that, due to their significant characteristics, can mostly be called agencies, or agency - type organizations. Their founding is connected with liberalization and privatization of public services, as well as with entrepreneurial and market freedom and with Europeanization of Croatian public administration. They are based on the idea of regulatory state which, as such, holds the right of setting norms of behaviour in the market and certain sectors of public services. The deficiencies of Croatian private entities with public authorities are irrational system, non-existence of unique 
legal structure and thus insufficient harmonization of regulations, unjustness of founding and costs, insufficient cooperation with the respective ministries, deficiencies within the employment system and public procurement. Therefore, it is a positive thing that the aforementioned strategic document on development of public administration until 2020 stipulates, within rationalization of administration, the measure of legal structure and rationalization of system of legal entities with public authorities.

For the entire system of public administration, there is a great significance of regulations that structure the general administrative procedure and administrative judicature. New legal stipulations on general administrative proceeding that are effective from January 1, 2010 and new legal regulations on administrative judicature that are effective from January 1, 2012 have laid the cornerstone for modernization of administrative proceeding and administrative judicature as an integral part of reform efforts of the Republic of Croatia within the public administration system.

In spite of the generally good results, Croatian public administration has to strengthen their capacities and upgrade the European administrative standards and thusly fully include themselves in the European Administrative Space.

\section{REFERENCES}

\section{BOOKS AND ARTICLES}

1. Brevir, M., Key Concepts in Governance, Sage Publicatons, 2009

2. Josipović, T., Načela europskog prava u presudama Suda Europske zajednice, Narodne novine d.d., Zagreb, travanj 2005

3. Koprić, I., Europski upravni prostor - ispunjavanje europskih standarda u državama članicama $i$ kandidatima, u Europski upravni prostor, Institut za javnu upravu, Zagreb, 2012

4. Koprić, I., Prilagodbe hrvatske javne uprave europskim standardima, u Godišnjak Akademije pravne znanosti Hrvatske, br.1/2014

5. Koprić, I., Razvoj i problemi agencijskog modela s posebnim osvrtom na nezavisne regulatore, $u$ Agencije u Hrvatskoj, Institut za javnu upravu, Zagreb, 2013

6. Koprić, I., Teritorijalna organizacija Hrvatske: prema novom uređenju, u Nova upravno-teritorijalna organizacija Hrvatske, Hrvatska akademija znanosti i umetnosti, Zagreb, 2015

7. Kuhlmann, S., Wollman, H., Introduction to Comparative Public Administration: Administrative Systems and Reforms, Edward Elgar, 2014

8. Ljubanović, B., Novi upravni i upravnosudski postupak - slabe točke i problematične situacije, u Europeizacija upravnog sudovanja u Hrvatskoj, Institut za javnu upravu, Zagreb, 2014 
9. Ljubanović, B., Postupanje po novom Zakonu o općem upravnom postupku i posebni upravni postupci, u Modernizacija općeg upravnog postupka i javne uprave u Hrvatskoj, Suvremena javna uprava, Zagreb, 2009

10. Ljubanović, B., Upravno sudovanje u Republici Hrvatskoj, u Zbornik na Pravniot fakultet „Justinijan prvi“ vo Skopje, Skopje, 2011

11. Musa, A., Dobro upravljanje u hrvatskim regulacijskim agencijama: prema pravnom okviru, u Agencije u Hrvatskoj, Institut za javnu upravu, Zagreb, 2013

12. Omejec, J., Pravnost hrvatske države, u Hrvatska država i uprava, Hrvatska akademija znanosti i umjetnosti, Zagreb, 2008

13. Pusić, E., Hrvatska središnja državna uprava i usporedni upravni sustavi, Školska knjiga, Zagreb, 1997

14. Schwartze, European Administrative Law, Sweet and Maxwell, London, 2006

15. Smerdel, B., Ustavno uredenje europske Hrvatske, Narodne novine d.d., Zagreb, lipanj 2013

16. Verhoeven, M., The Constanzo Obligation, The Obligation of National Administrative Authorities in the Cas of Incompatibility between National Law and European Law, 2011

\section{EU LAW}

1. Directive 2006/123/EC of the European Parliament and of the Council of 12 December 2006 on Services in the Internal Market within the Official Journal of the European Union as of December 27, 2006

\section{NATIONAL ACTS}

1. Act on Internal Financial Control System in Public Sector, Official Gazette, No. 78/15

2. Act on Local and Regional Self - Government, Official Gazette, No. 33/01, 60/01, 129/05, $109 / 07,125 / 08,36 / 09,150 / 11,144 / 12,19 / 13,137 / 15$

3. Act on the State Administration System, Official Gazette, No. 150/11, 12/13, 93/16, 104/16

4. Administrative Disputes Act, Official Gazette, No. 20/10, 143/12, 152/14, 94/16

5. Constitution of the Republic of Croatia (Consolidated text), Official Gazette, No. 5/14

6. Constitutional decision on sovereignty and independence of the Republic of Croatia, Official Gazette, No. 31/91

7. Croatian General Administrative Procedure Act, Official Gazette, No.47/09

8. Croatian Parliament, Strategy of Development of Public Administration from 2015 to 2020

9. European Charter of Local Self-government, Official Gazette, International Treaties, No. $14 / 97$ 